\title{
Meso-level investment management in transport projects with the application of the public- private partnership mechanism
}

\author{
Sergei A. Pravkin ${ }^{1}$, Vera V. Smirnova ${ }^{1,{ }^{*}}$, Rosalina V. Shagieva ${ }^{2}$, Igor V. Arkhipov ${ }^{3}$, and \\ Diana V. Erofeeva ${ }^{4}$ \\ ${ }^{1}$ Russian University of Transport (MIIT), Obraztsova st., 9, 9, 127994 Moscow, Russia \\ ${ }^{2}$ State University of Management, Ryazansky pr., 99, 109542 Moscow, Russia \\ ${ }^{3}$ Russian State University of Justice, Novocheremushkinskaya st., 69, 117418 Moscow, Russia \\ ${ }^{4}$ Russian Academy of Advocacy and Notaries, Maly Poluyaroslavsky lane, 3/5,1, 107120 Moscow, \\ Russia
}

\begin{abstract}
The rail freight market will develop more successfully, considering the specifics of the application of transport and investment legislation. Railway infrastructure investment can rely on selected mesolevel public-private partnership models. The authors propose to use the advantages of public-private partnership, its application, considering the regional specifics on the example of the rail freight transportation market as a meso-level institution. The proposed models of legal regulation of investments in transport projects can give a systemic economic and legal effect concerning spatially extended markets. Based on the wellestablished guidelines for the development of models of public-private partnerships in transport projects and the unification of legislation in the world market, the author proposes ways to improve Russian legislation concerning the development of the market for the transportation of goods by rail, based on the meso-economic approach.
\end{abstract}

\section{Introduction}

The meso-economic approach to economic development can be combined with various models of public-private partnership, which generally reduces administrative barriers to financing and is a systemic factor in the growth of the economy as a whole or of the mesolevel economy. Even accession to the WTO gave rise to many problems in the development of sectoral markets, increased "the need to develop a theoretical basis for government regulatory decisions regarding both priority sectoral markets and markets which may be exposed to undesirable transformations and problems" [1]. There was a need to develop modern approaches to legal regulation of spatially structured sectoral markets, which is the market of freight transportation by rail. The effectiveness of state regulation with the mesoeconomic approach is considered as an economic effect distributed in space and time when

\footnotetext{
${ }^{*}$ Corresponding author: veryvera@list.ru
} 
a certain regulator is turned on, in this case, based on the mechanism of a public-private partnership with the distribution of risks between the public and private partners.

The meso-economic approach involves an analysis of regional problems of sectoral markets, including the rail transport market, which should become an element of an innovative development system, considering the use of public-private partnership models. The projects being implemented within the framework of public-private partnerships are more regionally specific, including in relation to investment in railway infrastructure. "If we consider regional innovative development, it is reasonable to apply the following classification by types: spatial-geographical, sectoral, and by the scope of production activities" [2]. The most important tool for the development of spatially oriented markets, including the rail freight transportation market, is a public-private partnership. "Today, a private-public partnership is one of the prerequisites for increasing investment activity and the country's competitiveness, an incentive for the development of industrial and social infrastructures" [3]. To reduce the risks of railway transportation, optimize the transport system and create conditions for economic growth at the meso-level, providing an outlet for improving the transportation mechanism at the regional level, the systemic application of multimodal transportation of goods, which is facilitated by the implementation of publicprivate partnership mechanisms on transport systems [4]. Leading countries introduce an asset management model in the implementation of the transportation process. This model "ensures the efficient operation of railway transport under limited financial resources, where the main goal is to achieve a balance between costs, risks, and the required performance of assets" [5]. Application of the mechanism of a public-private partnership concerning the meso-economic approach must consider world experience. "The analysis of randomly selected 915 foreign projects in countries with different economic development, implemented using the concession form of PPP, showed that such partnerships are successfully used in transport (roads, railways, airports, ports, pipeline transport) and social infrastructure" [6].

\section{Material and methods}

The research methodology consisted of an analysis of the meso-level state management of the economy, a formal legal approach associated with the study of the problems of combining transport and investment legislation, and legal regulation of sectoral markets. Method of interpretation of the rules of law used to explain the legal norms of the current investment and transport legislation, which is aimed at explaining special terms and legal constructs for their application in legal practice. The comparative method was used to compare individual models of public-private partnership and the meso-economic approach, which was applied in respect to regional specifics, intersectoral, spatial and structural ties, social specifics to improve legislation regulating the activities of sectoral markets on its basis. The method of developing legal solutions was applied to develop proposals for eliminating legislative problems.

\section{Results}

In addition to financial support measures, an important point of state investment management is the direct participation of the state through the provision of budget investments and budget loans, the contribution of property to the authorized capital, and support for a public partner in public-private partnership projects.

The development of the transportation market is associated with the constant development of infrastructure, transport management systems, concerning the natural 
predominance of railway transport. To create conditions for investment in railway transport facilities, the Railway Transport Development Strategy 2030 was approved by the Government on June 17, 2008. The effective implementation of the Transport Strategy requires more active measures of budgetary incentives [7]. The main content of the Transport Strategy is the search for investment attractiveness with the participation of the state. At the same time, it is necessary to consider the global competition in the markets, the strengthening of the innovation component as a factor of the meso-level, which will make it possible to gradually abandon the economy of the raw material type.

The development of the transport and logistics complex is successfully proceeding through the introduction of the mechanism of public-private partnership as a meso-level factor. The Transport Strategy provides for the development of public-private partnership models for both development options - conservative and innovative, focusing on the socalled "polycentric model of the spatial development of Russia", which acts as a meso-level of the economy. The target is an innovative development, however, when switching to this variant, there is a need to increase the availability and quality of transport services [8], to focus on the wider participation of private business in such projects based on public-private partnerships.

Today, the state cannot without private investment independently invest in significant infrastructure projects. "The Russian practice of state and municipal PPP management have been developed and improved financing mechanisms for infrastructure projects and proposed a wide range of software products to automate the management of investments and debt obligations" [9]. Public-private partnership projects actively implement the principle of ensuring a competitive environment in the economy, combining the rights of public and private partners at the meso level.

As part of the implementation of the Transport Strategy, Russian Railways plans to participate in financing target programs, introduce an investment component in freight rates, and widely use public-private partnership models for the implementation of infrastructure projects. All of this is important for economic growth, as the reduction of management costs and the optimization of requirements create an economic effect. This effect can also be traced at the meso-level, where spatially extended markets, such as the rail transportation market, are located.

The meso-level is a process of intra-industry interactions of economic entities; the object of analysis is spatially extended (regional economic) structures. "The theory of meso-economic research defines three main directions of development: 1) a systemic approach: understanding the meso-level as a process of intra-industry interactions between economic entities to harmonize the economic system; 2) a regional-spatial approach; and 3) a theoretical approach in terms of methodological institutionalism, developed within the framework of the interdisciplinary intersections of economics and sociology" [10]. At the same time, the economy at this level is associated with other levels - politics, sociology, law, etc. This is a set of economic systems and subsystems from the highest to the lowest level, i.e., to the analysis of the meso-level of a particular enterprise, in this case, a single economic entity - JSC Russian Railways (sectoral meso-economics). Others also correspond to this level: intersectoral, regional-spatial, interregional. This is how mesoeconomic systems are modeled, including models of their development and sectors, for example, zones of special economic development, a concession model, models of publicprivate partnerships, etc. The tasks of the meso-level are thus complemented by the goals of innovative development, which is possible through the effective attraction of investments in industrial markets, including the rail freight transportation market.

Innovations based on the widespread attraction of investments create a classic mesolevel, which combines macro- and microeconomic approaches. Formal (traditional for the economy) and informal institutions are developing. This level unites the economy of the 
country, enterprises, organizations, individuals. This is precisely what the Transport Strategy is aimed at in its innovative version, where the development of transport is interconnected with the development, for example, of transport mobility of the population, which depends on the level of income (socioeconomics). The economy is a social system. Each individual in this system takes his place, receiving a significant service from the company. State, including legal regulators, are an integral part of meso-institutes. "PPP develops based on the current legislation on model agreements of a public-private partnership with clear segregation of obligations, risks, and responsibilities of partners: state and municipal authorities and private companies" [11]. Investment management based on a public-private partnership with the distribution of risks of the parties in entrepreneurship is a meso-institute. Meso-economics focuses on the study of its stable institutions. Spatial institutions of the meso-level can give systemic economic growth using the example of Russian Railways, which are sustainable over time. Spatial shifts are also possible to achieve in the development of the system, for example, due to high-speed railways, modernization of main highways, integrated development of public and nonpublic roads, hub ports according to the "Rotterdam variant" based on multimodal transportation. At the same time, much will depend on the applied mechanism of publicprivate partnerships in the state regulation of this activity. The methodological significance of the meso-level is decisive for the development of the Transport Strategy of Russia.

The meso-level strategy as a spatial development strategy is easily superimposed on the Transport Strategy, the railway transport development subprogram, and the development of the commercial rail freight market infrastructure (CMI).

All models of public-private partnerships are related to the functions that implement maintenance, operation, construction, design, etc. On March 19, 2019, the Government by Order No. 466-r approved a long-term development program for Russian Railways until 2025 , which involves a transition to a digital railway to expand and improve the quality of transport and logistics services through a digital format. In the field of railway transport, a unified information system is being created for organizing transportation. At the same time, the Digital Transport and Logistics project of the Ministry of Transport is being implemented. Services for the interaction of transport companies are being created by including them in the work of transport exchanges as special operational management systems that provide for the sale of transport services. At the same time, the legislation requires the development of a special legal regime for the use of information control and management tools in transport.

The legal regulation of the transport industry lags behind the calls of the time, which is manifested in the underdeveloped mechanisms of public-private partnerships in comparison with foreign experience. The use of public-private partnerships in the transport sector as a meso-level factor is becoming an important trend in solving state problems. At the same time, it is necessary to develop the availability of transport services by developing a competitive environment. The investment strategy of Russian Railways, which takes into account the widespread use of the partnership model, should be aimed at ensuring uninterrupted and safe transportation.

\section{Conclusion}

There is obvious importance to search for new legal models for the use of railway transport, which could become a locomotive to pull the Russian economy out of stagnation, contribute to the more successful development of sectoral markets based on a mesoeconomic approach, with the use of public-private partnership models. Public-private partnership is a meso-institute in the institutional model of investment in transport infrastructure. Its application will contribute to the development of meso-structures. It 
should be borne in mind that JSC Russian Railways spatially forms a certain meso-level of the economy. The rules and regulatory procedures themselves in a certain format must and are already moving to the meso-level, mainly through electronic interaction, through Internet platforms, providing visual control over traffic on highways.

Concerning the Transport Strategy, the use of the public-private partnership mechanism turns it into a tool for economic growth. The rail transport market is a spatially structured institution. In terms of the meso-economic approach, the development of the rail freight market can turn not only into a stabilizing factor of the economy but also, due to the spatial development of the railway network throughout the country, propel the Russian economy to a fast pace of development. Thus, the meso-economic approach makes it possible to reveal the effectiveness of state regulation of sectoral markets. Excessive sectoral breakdown or fragmentation of the economy must be overcome, realizing that economic development according to an innovative option is possible only in an integral system, such as a mesoeconomic system [12]. In the absence of an integral economic model of the economy, if it remains fragmented, the successful development of the sectoral market will not provide an incentive for other markets, even in a single development space. Therefore, the railway transport market should move in its development to the management of multimodal transportation based on a meso-economic approach with the widespread use of publicprivate partnerships as a system of co-investment, co-regulation, and risk distribution. The meso-level is the link between the macro- and micro-levels. It allows achieving the necessary changes and equilibrium through the creation of aggregates of enterprises, commercial and industrial, financial, and industrial groups, an example of which is JSC Russian Railways.

\section{References}

1. A.Kh. Shogenov, State regulation of industry markets, Author's abstract of the Candidate in Economics, 26 (2012)

2. K.V. Nazvanova, P.N. Zakharov, Modern management technologies, 9(57) (2015)

3. N.N. Semenova, T.V. Ermoshina, Russian Journal of Entrepreneurship, 18(10), 1567 (2017)

4. N.A. Butakova, Management consulting, 4, 199 (2016)

5. Iu.V. Dotsenko, A.A. Kharina, Collected scientific papers of Donizht, 5, 43 (2019)

6. G.F. Galiullina, S.B. Kuznetsova, L.B. Mingaleva, Modern studies of social problems, 3(35) (2014)

7. S.A. Pravkin, V.V Smirnova, Y.N. Bogdanov, I.I. Belozerova, N. Selezneva, V.V. Nasonkin, Turismo: Estudos \& Práticas (UERN), Mossoró/RN, Caderno Suplementar 01 (2019)

8. S.A. Pravkin, V.V. Smirnova, Transport Law and Security, 4(32), 134 (2019)

9. V.V. Ivanov, M.M. Zhabina, Russian foreign economic bulletin, 6, 20 (2015)

10. A.I. Volynskii, Journal of institutional studies, 9(3), 36 (2017)

11. E.V. Egorov, N.V. Romanova,V.V. Tsalikova,Timur Mishaki, Mediterranean Journal of Social Sciences, 5(18) (2014)

12. V.I. Maevskii, S.G. Kirdina-Chandler, M.A. Deriabina, Mesoeconomics: state and prospects, Monograph, 314 (2018) 